\title{
Pain management with morphine: variation in analgesic response secondary to genetic polymorphisms
}

This article was published in the following Dove Press journal:

Therapeutics and Clinical Risk Management

19 May 2012

Number of times this article has been viewed

\author{
Shailendra Kapoor \\ Mechanicsville, Richmond,VA, USA
}

Correspondence: Shailendra Kapoor

2300 E Cary St Richmond,

VA 23223, USA

$\mathrm{Tel}+\mathrm{I} 8042342345$

Fax + I 804345456 |

Email shailendrakapoor@yahoo.com

\section{To the editor}

The recent article by Villesen et al in a recent issue of your journal was most interesting. ${ }^{1}$ Recent studies show that the potency of morphine in efficacious pain control may be influenced greatly by polymorphisms of certain genes.

For instance, Klepstad et al have recently shown that cancer patients on opioid maintenance therapy who are homozygous for the variant $\mathrm{G}$ allele of the $118 \mathrm{~A}>\mathrm{G}$ polymorphism of the mu opioid receptor (OPRM1) gene require higher doses of morphine for efficacious pain control in comparison with patients who are heterozygous. ${ }^{2}$ In fact, the morphine requirement is almost $93 \%$ less in AA genotypes in contrast with morphine requirements in cancer patients who carry the GG genotype of the OPRM1 gene. ${ }^{3}$ Similar pain modulation variation is seen with polymorphisms of the OPRM1 gene and perioperative fentanyl administration. ${ }^{4}$ Furthermore, more profound CNS depressant side effects after morphine administration are noticed in cancer patients with certain polymorphisms of the multidrug resistance- 1 gene. ${ }^{5}$

Similarly, the potency of morphine in pain management in cancer patients is influenced and varies greatly with polymorphisms of the catechol-O-methyl transferase gene. ${ }^{6}$ For instance, individuals with the Met/Met genotype of the catechol-O-methyl transferase gene require $63 \%$ less morphine in comparison with those who have the Val/Val genotype of the catechol-O-methyl transferase gene. ${ }^{3}$ More profound central nervous system side effects are seen following morphine administration in cancer patients with single nucleotide polymorphisms in intron 1 of the catechol-O-methyl transferase gene. ${ }^{5}$

The above examples clearly illustrate the variation in adequate pain control with morphine secondary to genetic mutations. Further research is needed to identify other similar gene polymorphisms that may affect opioid requirements in patients being managed with other nonmorphine narcotics.

\section{References}

1. Villesen HH, Banning AM, Petersen RH, et al. Pharmacokinetics of morphine and oxycodone following intravenous administration in elderly patients. Ther Clin Risk Manag. 2007;3:961-967.

2. Klepstad P, Rakvag TT, Kaasa S, et al. The $118 \mathrm{~A}>$ G polymorphism in the human mu opioid receptor gene may increase morphine requirements in patients with pain caused by malignant disease. Acta Anaesthesiol Scand. 2004;48:1232-1239.

3. Reyes-Gibby CC, Shete S, Rakvag T, et al. Exploring joint effects of genes and the clinical efficacy of morphine for cancer pain: OPRM1 and COMT gene. Pain. 2007;130:25-30. 
4. Wu WD, Wang Y, Fang YM, Zhou HY. Polymorphism of the micro-opioid receptor gene (OPRM1 $118 \mathrm{~A}>\mathrm{G}$ ) affects fentanyl-induced analgesia during anesthesia and recovery. Mol Diagn Ther. 2009;13:331-337.

5. Ross JR, Riley J, Taegetmeyer AB, et al. Genetic variation and response to morphine in cancer patients: catechol-O-methyltransferase and multidrug resistance-1 gene polymorphisms are associated with central side effects. Cancer. 2008;112:1390-1403.
6. Rakvag TT, Ross JR, Sato H, Skorpen F, Kaasa S, Klepstad P. Genetic variation in the catechol-O-methyltransferase (COMT) gene and morphine requirements in cancer patients with pain. Mol Pain. 2008;4:64.

\section{Publish your work in this journal}

Therapeutics and Clinical Risk Management is an international, peerreviewed journal of clinical therapeutics and risk management, focusing on concise rapid reporting of clinical studies in all therapeutic areas, outcomes, safety, and programs for the effective, safe, and sustained use of medicines. This journal is indexed on PubMed Central, CAS,
EMBase, Scopus and the Elsevier Bibliographic databases. The manuscript management system is completely online and includes a very quick and fair peer-review system, which is all easy to use. Visit http://www.dovepress.com/testimonials.php to read real quotes from published authors.

Submit your manuscript here: http://www.dovepress.com/therapeutics-and-clinical-risk-management-journal 